\title{
Nonprofit Responses to Financial Uncertainty: How Does Financial Vulnerability Shape Nonprofit Collaboration?
}

\author{
Heather MacIndoe ${ }^{1} \&$ Felicia Sullivan ${ }^{1}$ \\ ${ }^{1}$ John W. McCormack Graduate School of Policy and Global Studies, University of Massachusetts Boston, \\ Boston, Massachusetts, USA \\ Correspondence: Heather MacIndoe, Department of Public Policy and Public Affairs, John W. McCormack \\ Graduate School of Policy and Global Studies, University of Massachusetts Boston, Boston, Massachusetts, \\ 02125 USA. Tel: 1-617-287-4861. E-mail: heather.macindoe@umb.edu
}

Received: May 13, 2014

Accepted: June 6, 2014 Online Published: August 29, 2014

doi:10.5539/jms.v4n3p1

URL: http://dx.doi.org/10.5539/jms.v4n3p1

\begin{abstract}
Nonprofit organizations are a vital part of the U.S. social safety net providing a wide range of services in the modern welfare state. While many individuals and families turn to nonprofits for help during economically challenging times, these organizations themselves often face turbulent funding environments and uncertain financial futures. Nonprofit stakeholders urge within-sector collaborations (with other nonprofits) and cross-sector collaborations (with for-profit firms and government agencies) as a means to achieve efficiencies in service delivery, stretch donation dollars, and increase the long-term fiscal sustainability of the nonprofit sector. While increased financial stability is a presumed outcome of nonprofit collaborations, we know little about the antecedent effect of nonprofit financial vulnerability on collaboration. Using data from a survey of nonprofit executive directors in Boston, Massachusetts, this paper examines how nonprofit financial vulnerability influences nonprofit collaborations. We find that nonprofit financial vulnerability decreases the likelihood of both within- and cross-sector collaborations. Resource dependence on private funding increases within-sector collaboration with other nonprofits, while reliance on government funding increases the likelihood of cross-sector collaboration. Cross-sector board linkages also increase the likelihood of collaborations. Nonprofit stakeholders should consider these findings when promoting collaboration as a path to nonprofit fiscal sustainability.
\end{abstract}

Keywords: nonprofits, financial vulnerability, sustainability, within-sector collaboration, cross-sector collaboration

\section{Introduction}

As greater numbers of individuals, families, and communities turn to nonprofit organizations for assistance during economically challenging times, these organizations themselves face increasingly turbulent funding environments (Besel, Williams, \& Klak, 2011; Miller, 2010). Nonprofits must navigate fragmented funding streams, weather economic fluctuations, and contend with a variety of changes to traditional revenue sources (Young, 2007). For example, a recent Urban Institute report found that government support for human service nonprofits often fails to cover the full costs of services. As a result, nonprofits respond by reducing their level of services, raising additional funds, or reducing staff (Boris, de Leon, Roeger, \& Nikolov, 2010). Private funding is also changing. The rise of donor control, through donor-advised funds and other mechanisms, means that donor preferences, rather than nonprofit relationships and expertise, increasingly dictate the distribution of private donations (Ostrander, 2007). Given the importance of nonprofit service providers to the social safety net, stakeholders including philanthropic funders, practitioners, and public managers are concerned about fiscal sustainability in the nonprofit sector.

The Boston Foundation (TBF), one of the largest community foundations in the U.S., recently issued several reports examining the financial health and sustainability of the Massachusetts nonprofit sector (Keating, Pradhan, Wassall \& DeNatale, 2008; Pradhan \& Hindley, 2009; Pradhan \& Keating, 2012). (Note 1) The reports confirm the importance of nonprofits as service providers and underscore the sector's role as an economic engine (Werkema, Leiserson, \& Ansel, 2005), employing more than 16 percent of the Massachusetts workforce in 2011 (Moore, 2012). However, this research revealed that many nonprofits are caught in a "current services trap" in 
which organizational revenues barley cover the costs of current programs and services, with little if anything set aside as an economic cushion (Keating, Pradhan, Wassall \& DeNatale, 2008). The TBF report concludes with a call for nonprofits to respond to economic challenges by "restructuring, repositioning, and reinventing" (2008, p.104) their organizations to bolster the fiscal health of the sector. The researchers argue that Massachusetts nonprofits should "seriously consider mergers, strategic alliances and collaborations as a strategy to strengthen organizational balance sheets, enhance offerings, and create economies of scale and efficiency" (2009, p. 6).

Calls for increased nonprofit collaboration resonate with previous research citing proliferation in the numbers of nonprofits, duplication of organizational efforts, and geographic overlap in service delivery as threats to nonprofit sustainability (e.g., Eisenberg, 1997; Paarlberg \& Varda, 2009; Saxton \& Benson, 2005). Within- and cross-sector collaborations are urged as a means to achieve greater efficiencies in service delivery and to enhance long-term sustainability of the nonprofit sector and of individual organizations (Eisenberg, 1997; La Piana, 2010; Sowa, 2009; Suárez, 2011). While increased financial stability is a presumed outcome of nonprofit collaborations, we know little about the antecedent effect of nonprofit financial vulnerability on collaboration. In this paper we conceptualize inter-organizational collaborations as one response to financial uncertainty and use data from a survey of nonprofit executive directors in Boston, Massachusetts, to examine how nonprofit financial vulnerability influences within- and cross-sector collaborations. We find that nonprofit financial vulnerability generally decreases the likelihood of both within- and cross-sector collaborations. However, resource dependence and board linkages increase cross-sector collaborations. Nonprofit stakeholders should consider these findings when promoting collaboration as a path to nonprofit fiscal sustainability.

\section{Literature Review}

\subsection{Nonprofit Collaborations as a Response to Financial Uncertainty}

Nonprofit organizations respond to financial uncertainty in a variety of ways. Some responses to uncertain economic environments involve modifications to internal organizational practices, such as shifting organizational capacities and changing executive leadership (Young, 2004). For example, nonprofits can modify or reduce the services they offer, changing their organizational capacity in response to reduced financial resources (Gazley, 2010; Sowa, 2009). Nonprofit organizations can also engage new leadership at the board and managerial levels in order to enact new strategic approaches to challenges stemming from uncertain economic environments (Goldman \& Kahnweiler, 2000; Winkler, 2006). While these responses focus on internal changes to nonprofit practice or leadership, nonprofit organizations can also respond to uncertainty by changing how they relate to the external environment. Nonprofits can undertake new ventures, such as commercial enterprises, to raise additional revenues as a means to supplement donations and grants (Austin, 2000; Sowa, 2009; Young, 2004). Nonprofits can also engage in advocacy or lobbying on behalf of their service constituencies (or the nonprofit sector itself) to attempt to persuade policymakers to maintain or increase resource allocations for nonprofit programs (Balassiano \& Chandler, 2010; Hoefer, 2005; MacIndoe \& Whalen, 2013; McNutt \& Borland, 1999). Another response to uncertain environments, one recommended by numerous nonprofit stakeholders, is for nonprofits to participate in organizational collaborations or partnerships to bolster capacity and to enhance long-term economic sustainability.

\subsection{Pursuing Sustainability through Collaborations}

Following Guo and Acar, we define collaboration as: "what occurs when different nonprofit organizations work together to address problems through joint effort, resources, and decision-making and share ownership of the final product or service" (2005, pp. 342-343). A large literature suggests that collaborating with other organizations confers benefits on nonprofits including increased social and intellectual capital, improved innovation, more funding, greater staff retention, improved service provision, greater success at advocacy and increases in general organizational effectiveness (Bryson, Crosby, \& Stone, 2006; Johansen \& LeRoux, 2013; Selden, Sowa, \& Sandfort, 2006; Suárez, 2011). Collaboration is also seen as a means to build nonprofit financial sustainability. In the nonprofit context, sustainability is defined as the means by which an "organization will be able to fulfill its commitments to its clients, it patrons, and the community in which it operates" (Weerawardena, McDonald, \& Mort, 2010, p. 347). Collaborations contribute to sustainability by providing additional resources, skills, and knowledge that enable nonprofits to reach new constituents and to access new revenue streams (Mehta \& Mehta, 2010; Parker \& Selsky, 2004; Silver, 2004; Sowa, 2009). Organizational collaborations can lead to increased organizational effectiveness by reducing the transaction costs that accompany repeated interactions in activities such as joint service delivery (Provan \& Milward, 1995). Finally, collaborative arrangements can provide nonprofits with competitive advantages over their peers by situating them within information and resource networks (Guo \& Acar, 2005; Poole, 2008). 


\section{Research Questions and Hypotheses}

Underlying much of the talk about collaboration in the nonprofit sector is the presumption that collaborations make nonprofits more efficient and effective organizations. This paper examines the antecedent effect of nonprofit financial vulnerability on collaboration: How does financial vulnerability impact the likelihood that a nonprofit organization will engage in within-sector collaborations (with other nonprofits) or cross-sector collaborations (with for-profit firms or government agencies)? We examine three sets of influences on the likelihood that nonprofits engage in collaborations: financial vulnerability, resource dependence, and organizational characteristics and leadership.

\subsection{Nonprofit Financial Vulnerability}

A growing literature investigates correlates of fiscal health in the nonprofit sector (e.g., Bowman, 2011; Mayer, Wang, Egginton, \& Flint, 2014; Young, 2007). Initially, concepts used to evaluate for-profit firms, such as liquidity, profitability, and solvency, were applied to nonprofits. Early financial analyses of the nonprofit sector included measures of cash on hand, surplus margin, and leverage (Keating et al., 2008; Ohlson, 1980). Tuckman and Chang (1991, Chang \& Tuckman, 1994) proposed a method to understand financial vulnerability that accounted for the particular operating and funding contexts of nonprofit organizations. They identified four financial ratios which they argued could predict financial vulnerability in the nonprofit sector: equity (equity/total revenue), revenue concentration (Herfindahl Index), administrative costs (administrative expenses/total expenses), and surplus margin ((revenue-expenses)/revenue). Performance thresholds for each ratio were used to define "at-risk" nonprofits.

Subsequent research expanded on Tuckman and Chang's (1991, Chang \& Tuckman, 1994) seminal analyses of nonprofit financial vulnerability by investigating additional measures such as reliance on commercial revenue, and endowment sufficiency (Greenlee \& Trussel, 2000; Keating, Fischer, Gordon, \& Greenlee, 2005; Trussel, 2002). Researchers also evaluated the usefulness of Tuckman and Chang's measures of financial vulnerability for predicting nonprofit survival. In his analysis of survival among arts nonprofits, Hager (2001) found the Tuckman-Chang measures to be significant predictors of organizational demise, but suggests that the applicability of these measures may vary across nonprofit sub-groups. The use of financial ratios in the nonprofit sector is becoming part of the normative framework of how nonprofits report to stakeholders to ensure their continued support (Macguire, 2013).

While there is no consensus on a single indicator of nonprofit financial health, examining several financial ratios simultaneously has emerged as a common practice to assess the relationship between measures of nonprofit financial vulnerability and important outcomes such as survival (e.g., Hager 2001) and obtaining government funding and philanthropic support (e.g., Ashley \& Faulk, 2010; Ashley \& VanSlyke, 2012; Brooks 2004; Crittenden, 2000). We build on prior research by positing a relationship between nonprofit financial vulnerability and another important organizational outcome, engagement in within- and cross-sector collaborations.

Research demonstrates that inter-organizational collaborations require various financial, technological, administrative, or cultural capacities. Organizational resources are viewed as an important pre-requisite for successful collaborations. For example, in her study of collaborations between nonprofit land trusts and local governments Shaw (2003) found that relationships between key personnel, and a mutual understanding of different organizational cultures, helped to facilitate success in these public-private partnerships. However some nonprofit stakeholders, particularly private funders, urge nonprofits to partner with other organizations in order to compensate for a lack of resources, or to leverage the modest resources of multiple organizations (e.g., Eschenfelder, 2011; Keating, Pradhan, Wassall, \& DeNatale, 2008). These studies suggest that financial vulnerability, indicating a lack of organizational capacity, might increase or decrease nonprofits' likelihood of participating in inter-organizational collaborations (Note 2).

\section{H1: Financial vulnerability will influence nonprofit engagement in within- or cross-sector collaborations.}

\subsection{Resource Dependence}

Research shows that nonprofit resource dependence on particular sources of revenue shapes a variety of organizational practices (Pfeffer \& Salancik, 1978/2003). Funder accountability requirements shape nonprofit reporting and the use of various performance measures such as outcome measurement (Anheier, 2005; MacIndoe \& Barman, 2013). Several studies find that public funding decreases autonomy in nonprofit decision-making (e.g., Jung \& Moon, 2007; Nikolic \& Koontz, 2008; Verschuere \& De Corte, 2014). Decreased autonomy over decision-making may be a trade-off for the increased financial stability that can accompany public support (Froelich, 1999). Private philanthropic support also shapes nonprofit activities. In their study of 112 nonprofit 
organizations in central Florida, Hodge and Piccolo (2005) found that private philanthropic support was associated with more effective nonprofit boards, which led to increased fiscal oversight, minimizing financial vulnerability.

In addition to influencing internal organizational practices, public and private funders are increasingly impacting the formation of nonprofit partnerships with important consequences (Kettl, 2006). In a study based of 200 nonprofit leaders in the San Francisco Bay area, Suárez (2011) found that collaboration was essential to receiving government funding and resulted in more financial support from government sources. Some funders might make the award of grant dollars contingent upon evidence of collaborations or partnerships. This is especially true if program outcomes require action from more than one stakeholder group (Shaw, 2003). Funders might also use collaborations as a tool to restructure nonprofit relations. Eschenfelder (2011) explored such an effort through an in-depth case study of a government grantor that actively worked to restructure nine of its funded organizations into an integrated management service organization. The study found benefits for nonprofits beyond administrative and bottom line savings including increased reputation, new sources of funding, and peer support. Funders themselves are also increasingly looking to work in closer partnership with their grantees, sometimes with mixed results. In an exploratory study of grantor-grantee relationships, Fairfield and Wing (2008) found that foundation-nonprofit relationships varied in scope and tone, and that boundaries between personal and organizational roles created tensions that at times stymied collaborative efforts.

\section{H2: Nonprofit resource dependence will increase within- and cross-sector collaborations.}

\subsection{Organizational Characteristics and Leadership}

Other research examines how organizational characteristics (e.g., size, sector) and leadership (e.g., executive directors, board members) shape nonprofit collaborations (Gazley, 2010; Goldman \& Kahnweiler, 2000; Huxham \& Vangen, 2000). Structural features of organizations and relational dynamics within organizations are at the core of this body of research. For example, Trussel (2002) found that smaller nonprofit organizations were more financially vulnerable than their larger counterparts. Research suggests that size is related to other key organizational factors needed for sustainability such as reputation, experience, and the ability to create economies of scale (Carroll \& Stater, 2009; Ohlson, 1980; Tinkelman, 1999).

Some studies of nonprofit collaboration examine inter-organizational dynamics such as building trust, establishing common values, and creating mechanisms to support sharing and reciprocity between organizations (Gazley, 2008; Gazley, 2010; Parker \& Selsky, 2004; Sowa, 2009). Participation in organizational networks can increase communication, learning, and coordination (Gazley, 2010; Poole, 2008). Nonprofit organizations that belong to membership organizations or that serve multiple constituencies are likely to have more frequent contacts with peers and other stakeholders. As a result, they are able to extend their knowledge and resource networks, while building greater capacity to meet their programmatic missions.

Nonprofit leaders, including board members, shape program delivery, organizational strategy and resource development (Hodge \& Piccolo, 2005; Johnson, Daily \& Ellstrand, 1996; Nobbie \& Brudney, 2003). A recent study showed that board members who were activity engaged in oversight and resource development improved the financial stability of nonprofit organizations, especially if the organization received funding from private philanthropic sources (Verschuere \& De Corte, 2014). Other studies support this finding confirming that boards impact the financial sustainability of nonprofit organizations (Crittenden, 2000; Hodge \& Piccolo, 2005; Jackson \& Holland, 1998). Board members may also provide critical links to external entities (e.g., nonprofits, government agencies, funders, influential individuals). The complex web of social relationships created by individuals who sit on multiple boards, interlocking directorates, are the sources of relational networks that create potential pathways for collaboration (Mizruchi, 1996; Scott, 1990; Vidovoch \& Currie, 2012).

H3: Nonprofit capacity, indicated by age, size (revenue), serving multiple constituencies, and belonging to a professional association will increase collaboration.

H4: The presence of nonprofit leaders (board members) that have within- or cross-sector affiliations will increase nonprofit involvement in collaborations.

\section{Methodology}

\subsection{Sample and Nonprofit Survey}

We examine the relationship between nonprofit financial vulnerability and collaboration using data from the Boston Area Nonprofit Study, a survey of nonprofit organizations located in metropolitan Boston, Massachusetts. The nonprofit sample was drawn from the 2008 Business Master File maintained by the National Center for Charitable Statistics at the Urban Institute, the national repository of data on the nonprofit sector in the United 
States. The sample was stratified by organizational mission, size (expenses), and geographic location (Boston neighborhoods). While the study included organizations from across nonprofit sub-sectors (e.g., human services, education, etc.) all organizations in the sample provided services to clients or members. The sample excluded universities, hospitals, and philanthropic foundations since previous research indicates that these nonprofits are likely to collaborate in ways that systematically vary from the rest of the nonprofit population (e.g., Fairfield \& Wing 2008; Silver, 2004). The sample also excluded religious organizations and organizations with less than $\$ 25,000$ in revenue that are not required to register with the Internal Revenue Service.

The University of Chicago Survey Lab administered the online survey between September 2008 and February 2009. Executive directors provided information about a range of organizational attributes and practices, including whether their nonprofit participated in within- and cross- sector collaborations in the previous fiscal year. The survey achieved a sixty-three percent response rate $(\mathrm{N}=379)$.

\subsection{Analytic Strategy and Dependent Variables}

We estimate logistic regression models to explain whether a nonprofit organization reported within-sector collaborations (with other nonprofits), or cross-sector collaborations (with for-profit firms, state or local governments, or the federal government). Logistic regression is appropriate given the dichotomous nature of our dependent variables (Menard, 2002). We report the odds ratios, the exponential function of the regression coefficients $\left(\mathbf{e}^{\mathbf{B} 1}\right)$, which describe the odds of an event (e.g., within-sector collaboration) occurring in one group (e.g., nonprofits that are dependent on foundation grants), to the odds of the event occurring in another group (e.g., nonprofits that are not dependent on foundation support), with the other variables in the model held constant.

Table 1 reports descriptive statistics for the variables in the analysis. The four dependent variables are dichotomous measures indicating whether a nonprofit reported engaging in within-sector collaborations (with other nonprofits), or cross-sector collaborations (state or local government, the federal government, or for-profit firms) in the last fiscal year.

\subsection{Independent Variables}

The regression models investigate the influence of three sets of factors on nonprofit collaborations: financial vulnerability, resource dependence, and organizational characteristics and leadership.

\subsubsection{Measures of Financial Vulnerability}

The main independent variables of interest are measures of nonprofit financial vulnerability. The literature on nonprofit financial health examines a variety of measures and has not yet reached a consensus around a particular set of financial indicators. We investigated a wide variety of financial measures drawn from the nonprofit literature and selected five measures of financial vulnerability that captured different aspects of vulnerability. These measures were not highly correlated. (Note 3) The measures of financial vulnerability included in the regression models are: funding disruption, debt ratio, administrative expense ratio, Herfindahl Index of revenue concentration, and reliance on commercial income. See Appendix A "Description of Measures of Nonprofit Financial Vulnerability" for detailed definitions, formulas, and citations to previous research using these measures.

Financial vulnerability is measured prior to the survey reports concerning nonprofit engagement in collaboration. Measures of financial vulnerability were calculated using financial data available from the National Center for Charitable Statistics Digitized Data File (2006) for the most recently available year of data prior to the 2008-2009 nonprofit survey (National Center for Charitable Statistics, 2013).

\subsubsection{Measures of Resource Dependence, Organizational Characteristics and Leadership}

Resource dependence is measured using nonprofit survey responses indicating whether government, foundation, or United Way funding was one of the organization's primary sources of income in the last fiscal year. The key variables measuring organizational characteristics included nonprofit mission, age, size (expenses), whether a nonprofit serves multiple constituencies, and if a nonprofit belongs to a membership association. The models also included indicators of the presence of certain types of organizational leaders: nonprofit board members from other nonprofits, government agencies, or for-profit firms. Appendix B provides correlations for variables in the regression models. 
Table 1. Descriptives

\begin{tabular}{|c|c|c|c|}
\hline Variables $^{1}$ & Mean & SD & Operationalization \\
\hline \multicolumn{4}{|l|}{ Dependent Variables } \\
\hline Within Sector Collaborations & & & In the last fiscal year has your organization collaborated with: \\
\hline Nonprofit Organizations & .86 & .35 & another nonprofit? \\
\hline Cross-Sector Collaborations & & & In the last fiscal year has your organization collaborated with: \\
\hline State/Local Government & 69 & .46 & a state/local government entity/agency? \\
\hline Federal Government & .31 & .46 & a federal government entity/agency? \\
\hline For-Profit Firms & .58 & .49 & a for-profit firm? \\
\hline \multicolumn{4}{|l|}{ Independent Variables } \\
\hline Measures of Financial Vulnerability ${ }^{2,3}$ & & & As value increases nonprofit: \\
\hline Funding Disruption & .67 & 4.61 & Is more vulnerable to changes in funding \\
\hline Debt Ratio & .89 & 9.40 & Is more encumbered by debt \\
\hline Administrative Expense Ratio & .15 & .14 & Has greater administrative expenses \\
\hline Herfindahl Index (normalized) & .52 & .24 & Revenues are concentrated in fewer sources \\
\hline Reliance on Commercial Revenue & .35 & .35 & Is more reliant on commercial income \\
\hline \multicolumn{4}{|l|}{ Measures of Resource Dependence } \\
\hline Government Revenue & .35 & .48 & Government funding is top 1 or 2 source of revenue \\
\hline Foundation Revenue & .42 & .49 & Foundation funding is top 1 or 2 source of revenue \\
\hline United Way Revenue & .12 & .32 & United Way funding is top 1 or 2 source of revenue \\
\hline \multicolumn{4}{|c|}{ Organizational Characteristics and Leadership } \\
\hline \multicolumn{4}{|l|}{ Nonprofit Mission ${ }^{4}$} \\
\hline Health \& Human Services & .30 & .46 & e.g., food banks, shelters, community health clinics \\
\hline Arts \& Culture & .26 & .44 & e.g., museums, performing arts organizations \\
\hline Education & .20 & .40 & e.g., adult education, libraries, after-school programs \\
\hline Public Benefit & .25 & .43 & e.g., neighborhood associations, rights-based organizations \\
\hline Organizational Age & 23 & 19 & Age (years) in 2009 based on IRS rule date \\
\hline Organizational Size & .34 & 1.26 & Natural log of annual expenses \\
\hline Serving Multiple Constituencies & 1.41 & .49 & Nonprofit reports multiple service constituencies \\
\hline Professional Association Member & .34 & .48 & Nonprofit belongs to a membership association \\
\hline \multicolumn{4}{|l|}{ NPO Board Member Affiliated With: } \\
\hline Another Nonprofit & .59 & .49 & Board member affiliated with another nonprofit \\
\hline Government Agency & .15 & .36 & Board member affiliated with a government agency \\
\hline For-Profit Firm & .50 & .50 & Board member affiliated with a for-profit firm \\
\hline
\end{tabular}

Notes. ${ }^{1}$ Unless otherwise indicated, all data come from the Boston Area Nonprofit Study (N=379). ${ }^{2}$ See Appendix A for definitions and equations describing these financial ratios. ${ }^{3}$ Data from the National Center for Charitable Statistics at the Urban Institute, Washington, D.C. (Digitized Data File 2006). ${ }^{4}$ Classified using the National Taxonomy of Exempt Entities, the U.S. classification system for nonprofit mission.

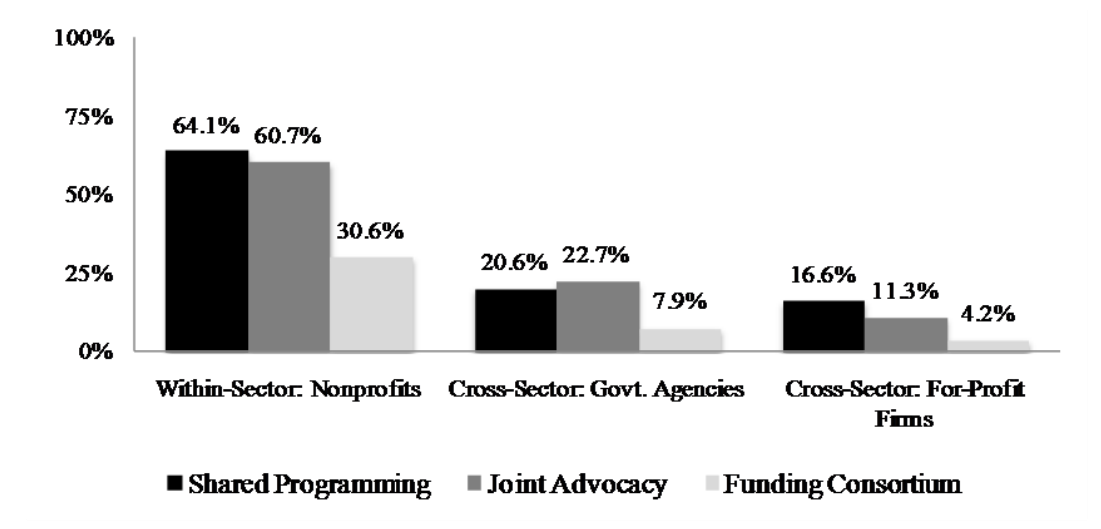

Figure 1. Purposes of within- and cross-sector collaborations in the Boston nonprofit sector

Source: Boston Area Nonprofit Study. 


\section{Results and Discussion}

Most nonprofits reported engaging in within- or cross-sector collaborations. Within-sector collaborations were the norm: 86 percent of Boston nonprofits reported collaborating with other nonprofits. Reports of cross-sector collaborations were less frequent: 69 percent of nonprofits collaborated with state/local governments, 31 percent with the federal government, and 58 percent with for-profit firms. While the focus of this paper is on the presence or absence of nonprofit collaborations, it is important to consider that nonprofits collaborate within and across sectors for different purposes. Figure 1 shows the percent of nonprofits in the sample that reported collaborating within and across sectors for three distinct purposes: shared programming, joint advocacy, and funding consortiums. Patterns of within- and cross-sector collaborations are consistent across the different purposes. Collaboration for all purposes is greatest with other nonprofits, followed by government agencies, then for-profit firms.

Table 2 reports the odds ratios for logistic regressions predicting within- and cross-sector collaborations reported by the sample of Boston nonprofits. Three sets of independent variables measuring financial vulnerability, resource dependence, and organizational characteristics and leadership, are included in the analyses. Model 1 (Table 2) predicts whether a nonprofit engaged in a within-sector collaboration with another nonprofit in the last fiscal year. Models 2 to 4 (Table 2) predict nonprofit participation in cross-sector collaborations with government agencies and for-profit firms. A few general observations can be made about these models. First, measures of nonprofit financial vulnerability are statistically significant, generally negative, predictors of within- and cross-sector collaborations. Second, resource dependence measures are strong positive predictors of nonprofit collaboration. Reliance on private funding sources (philanthropic foundation and United Way grants) is a significant positive predictor of both within- and cross-sector collaborations. Reliance on public funding is

Table 2. Odds ratios for logistic regression models predicting nonprofit collaboration

\begin{tabular}{|c|c|c|c|c|c|c|c|c|}
\hline & \multirow{2}{*}{\multicolumn{2}{|c|}{$\begin{array}{c}\begin{array}{l}\text { Within Sector } \\
\text { Collaborations }\end{array} \\
\text { Model } 1 \\
\text { Nonprofits }\end{array}$}} & \multicolumn{6}{|c|}{ Cross-Sector Collaborations } \\
\hline & & & \multicolumn{2}{|c|}{$\begin{array}{c}\text { Model } 2 \\
\text { State/Local Govt. }\end{array}$} & \multicolumn{2}{|c|}{$\begin{array}{l}\text { Model } 3 \\
\text { Federal Govt. }\end{array}$} & \multicolumn{2}{|c|}{$\begin{array}{c}\text { Model } 4 \\
\text { For-Profit Firms }\end{array}$} \\
\hline \multicolumn{9}{|l|}{ Measures of Financial Vulnerability } \\
\hline Funding Disruption & 0.95 & & 0.94 & \multirow{5}{*}{ * } & 0.90 & & 1.18 & \multirow{9}{*}{${ }^{* *}$} \\
\hline Debt Ratio & 1.62 & \multirow[b]{2}{*}{$*$} & 2.06 & & 1.09 & & 1.34 & \\
\hline Administrative Expense Ratio & 0.14 & & 0.50 & & 0.61 & & 0.69 & \\
\hline Herfindahl Index (normalized) & 0.22 & ** & 1.36 & & 0.80 & & 0.76 & \\
\hline Reliance on Commercial Revenue & 0.32 & $* *$ & 0.78 & & 0.45 & ${ }^{* *}$ & 0.37 & \\
\hline \multicolumn{8}{|l|}{ Resource Dependence } & \\
\hline Government Revenue & 1.93 & \multirow{3}{*}{${ }^{* * * *}$} & 3.17 & \multirow{3}{*}{$\begin{array}{l}{ }^{* * *} \\
* *\end{array}$} & 3.10 & $* * *$ & 0.81 & \\
\hline Foundation Revenue & 4.51 & & 2.21 & & 1.13 & & 1.03 & \\
\hline United Way Revenue & 8.67 & & 1.80 & & 2.03 & * & 1.60 & \\
\hline \multicolumn{9}{|c|}{ Organizational Characteristics and Leadership } \\
\hline \multicolumn{9}{|c|}{ Nonprofit Mission ${ }^{1}$} \\
\hline Arts \& Culture & 1.54 & \multirow{7}{*}{${ }^{* *}$} & 0.62 & & 0.59 & \multirow{7}{*}{ *** } & 0.90 & \\
\hline Education & 0.45 & & 0.77 & & 1.23 & & 1.30 & \\
\hline Public Benefit & 0.74 & & 1.05 & & 1.15 & & 1.62 & \\
\hline Organizational Age & 1.00 & & 1.00 & & 0.99 & & 1.01 & \\
\hline Organizational Size & 0.96 & & 1.09 & & 1.28 & & 1.09 & \\
\hline Serving Multiple Constituencies & 1.75 & & 0.84 & & 1.17 & & 1.19 & \\
\hline Professional Association Member ${ }^{2}$ & 1.89 & & 1.34 & & 1.35 & & 2.03 & ** \\
\hline \multicolumn{9}{|l|}{ NPO Board Member Affiliated With: } \\
\hline Another Nonprofit & 0.81 & & 1.02 & \multirow{3}{*}{ ** } & 1.13 & \multirow{3}{*}{$* * *$} & 1.56 & \multirow{3}{*}{$\begin{array}{l}* * \\
* * *\end{array}$} \\
\hline Government Agency & 1.04 & & 6.72 & & 4.57 & & 2.53 & \\
\hline For-Profit Firm & 1.55 & & 1.46 & & 0.90 & & 2.30 & \\
\hline Constant & 9.92 & \multirow[b]{2}{*}{$* * *$} & 0.36 & \multirow[b]{2}{*}{$* * *$} & 0.13 & $* * *$ & 0.16 & \multirow[b]{2}{*}{$* * *$} \\
\hline Chi-Square & 51.13 & & 68.37 & & 69.01 & ${ }^{* * * *}$ & 56.94 & \\
\hline
\end{tabular}

$* * * \mathrm{p}<.001, * * \mathrm{p}<.05, * \mathrm{p}<.10$

Notes. ${ }^{1}$ Reference category is health and human service organizations. ${ }^{2}$ To check for possible endogeneity in the models, we ran the analyses with and without this variable. Results for other variables were not affected. 
a strong positive influence on nonprofit collaborations with government agencies, but government funding does not influence within-sector collaborations with other nonprofits. Finally, organizational characteristics influence both within- and cross-sector collaborations. Leadership characteristics, measured as the presence of particular types of board members, are significant positive predictors of cross-sector, but not within-sector, collaborations. These findings are discussed in greater detail below.

\subsection{Financial Vulnerability}

The primary question motivating this paper is whether financial vulnerability impacts a nonprofit's likelihood of engaging in inter-organizational collaborations, which are thought to increase long-term financial sustainability in the nonprofit sector. In three of the four models, financial vulnerability is associated with a lower likelihood of collaboration. Financial vulnerability decreases the likelihood that a nonprofit will engage in within-sector collaborations with other nonprofit organizations. (H1 is supported.) According to Model 1, as nonprofits consume more of their resources in administrative expenses, have more concentrated revenue streams, and exhibit greater reliance on commercial income, they are less likely to partner with other nonprofits.

Financial vulnerability also impacts nonprofits' likelihood of engaging in cross-sector collaborations. Nonprofits that exhibit greater reliance on commercial income are less likely to collaborate with federal agencies and for-profit firms. It could be that a greater amount of commercial income provides increased autonomy, decreasing pressures from government grantors and private foundations to collaborate. It may also be that nonprofits that are reliant on commercial income view for-profit firms as competitors rather than collaborators. Nonprofits with higher debt ratios are more likely to collaborate with state and local governments. It may be that higher debt loads are associated with nonprofits that assume debt to cover organizational expenses that will eventually be reimbursed through government vouchers or contracts.

\subsection{Resource Dependence}

Nonprofit resource dependence plays a very important role in shaping both within- and cross-sector collaborations. (H2 is supported.) Interestingly, the propensity for nonprofits to engage in within-sector collaborations is driven by reliance on private, not public, funding sources. Nonprofits that ranked private foundation funding as a primary income source are 4.5 times more likely to partner with another nonprofit (than a nonprofit that did not identify foundation funding as an important source of revenue). Reliance on United Way funding has an even greater impact on within-sector collaborations. A nonprofit that identified United Way funding as a top revenue source is 8.7 times more likely to collaborate with other nonprofits (than an organization not as reliant on United Way funds). These findings reflect previous research emphasizing the important role that private philanthropic funders play in encouraging nonprofit collaborations (Shaw, 2003). United Way funding may also confer additional benefits to grantees as they are drawn into a local collaborative network structured by the United Way agency.

Resource dependence on private funding also influences cross-sector collaboration. Nonprofits that report dependence on foundation funding are 2.2 times more likely to collaborate with state/local governments, while nonprofits that are dependent on United Way funding are 2.0 times more likely to collaborate with federal agencies. Interestingly, dependence on government funding was a stronger predictor of cross-sector collaboration with local, state, or federal governments. Nonprofits that report government funding as a primary revenue source are 3.2 times more likely to collaborate with state, local and federal governments (than nonprofits that do not rely on government revenue). Collaborations may be the natural result of government and federated funding arrangements. These funders often look for evidence from potential nonprofit grantees of their capacity to fulfill service contracts and to comply with grant reporting. Public and private funding may also situate nonprofits in networks diffusing best practices and offering technical assistance.

\subsection{Organizational Characteristics and Leadership}

Nonprofit capacity influences both within- and cross-sector collaborations, though not all measures were significant predicators. (H3 is partially supported.) Neither nonprofit mission nor age influenced the likelihood of collaboration. Nonprofits that served multiple constituencies were 1.8 times more likely to collaborate with other nonprofits than organizations that identified as having one primary service constituency. Interestingly, having multiple constituencies did not impact cross-sector collaborations. This could reflect the large amount of within-sector nonprofit collaboration for purposes of service delivery. Within-sector collaborations may be less costly as nonprofits may share cultures, vocabularies, and systems that do not easily translate to the public or for-profit sectors (Gazley, 2008). Size also influenced collaborations, with larger nonprofits being more likely to collaborate with federal agencies. Given the complex bureaucratic systems required for securing, monitoring, 
and maintaining large federal grants, it is likely that organizational capacity is essential to manage a collaborative relationship with federal agencies. Interestingly, nonprofits that belong to a membership association are twice as likely (than nonprofits that do not belong to a membership association) to collaborate with for-profit firms. These networking organizations diffuse norms of communication, knowledge sharing, and resource coordination that may predispose nonprofits to engage in collaborations.

Nonprofit leadership as reflected in board representation does not appear to influence within-sector collaborations. (H4 is partially supported.) However, board representation does influence cross-sector collaborations. Nonprofits with a board member from a government agency are 6.7 times more likely to collaborate with state/local governments, and 4.6 times more likely to collaborate with federal agencies than nonprofits without such representatives on their boards. Nonprofits with a board member from the public sector are also 2.5 times more likely to collaborate with for-profit firms. Not surprisingly, nonprofits with for-profit leaders on their boards of directors are 2.3 times more likely to partner with other for-profit entities. Nonprofit board members may be an important source of information about perspective partnerships. Nonprofits interested in greater collaboration should consider the diversity of organizational and sector contacts represented on their boards of directors.

\section{Conclusion and Limitations}

\subsection{Conclusion}

This study contributes to the literature on nonprofit sustainability and financial vulnerability by examining inter-organizational collaborations, which are often touted as a solution to fragmentation and duplication of effort in the nonprofit sector. Our findings, that financially vulnerable nonprofits are less likely to engage in both within- and cross-sector collaborations, should serve as a cautionary note to public and private funders who urge collaboration to increase efficiency, effectiveness, and fiscal health in the nonprofit sector. Financially vulnerable nonprofits, the presumed beneficiaries of collaborations, may be less able to engage in collaborations, experience collaborations as more costly, and be quicker to exit collaborations formed solely at the behest of stakeholders such as philanthropic funders. Financially vulnerable nonprofits, particularly those with high administrative costs, concentrated revenues, and reliance on commercial income, may find themselves in a dual bind. While attempting to meet the collaborative demands of funders, they might also lack the financial capacity to meet such demands.

Some researchers relate nonprofit financial vulnerability to the "current services trap" (Keating, Pradhan, Wassall \& DeNatale, 2008). Other nonprofit observers refer to this as the "nonprofit starvation cycle" driven in part by funder reluctance to fund nonprofit infrastructure, and nonprofits' failure to educate funders about the true costs of doing business (Gregory \& Howard, 2009). These costs include those associated with collaborations. Depending on the nature of the collaboration, nonprofits can expend enormous resources when partnering with others (Gazley, 2008). Nonprofit managers seeking to enhance existing or establish new collaborations should be advised to consider how revenue sources and organizational leadership could constrain or facilitate planned collaborations. Funding agencies interested in promoting collaboration should consider providing incentives that endure beyond the initial grant period that establishes the collaboration. For example, professional membership organizations could provide board members and executive leadership with a mechanism for professional development that supports collaboration. Efforts to help nonprofits build capacity and economies of scale comparable to larger organizations may help, but calls for mergers and joint management should be undertaken with an understanding of the organizational capacities required by such efforts.

\subsection{Limitations}

This paper deepens our understanding of how nonprofit financial vulnerability influences collaboration, however some limitations should be acknowledged. Research on the use of nonprofit financial ratios continues to grow. Some studies question the appropriateness of using these measures to examine heterogeneous samples of nonprofits (Hager, 2001; Webb \& Abzug, 2013). Future research could investigate whether different measures of financial vulnerability influence different types of collaboration. For example, nonprofits with high administrative expense ratios may be more likely to participate in funding consortiums as a way to lower overall administrative costs associated with fundraising. Nonprofits at greater risk of funding disruption may be more likely to participate in collaborations that involve shared programming as a way to ensure that the needs of their service populations continue to be met.

A further limitation of this study might be that the nonprofit survey data was collected at the start of the economic downturn of 2008-2009. In retrospect, this may have artificially inflated levels of collaboration as nonprofits turned to partnerships to weather funding cuts and other fiscal challenges. Alternatively, our finding 
that nonprofit financial vulnerability generally depresses collaboration, suggests that the general level of nonprofit collaboration during the period of the study may be lower than what we might expect in a better economic environment. It is difficult to disentangle economic forces and collaboration, so we mention this as a possible limitation. Finally, while these analyses indicate a statistically significant relationship between financially vulnerability and a lower likelihood of collaboration, this data cannot tell us whether the financial vulnerability of prospective partners shapes the collaboration choices of nonprofit leaders, or even whether the fiscal health of their partners enters into the decision to collaborate. Additional research collecting qualitative data from nonprofit leaders is needed to address these questions.

\section{Acknowledgements}

The authors would like to acknowledge funding from The Boston Foundation, University of Massachusetts Boston (John W. McCormack Graduate School of Policy and Global Studies), and the Kennedy School of Government (Hauser Center for Nonprofit Organizations and Rappaport Institute for Greater Boston). A previous version of this paper was presented at the 2010 Association for Public Policy Analysis and Management. We thank Marc Lavine for helpful comments on an early draft.

\section{References}

Anheier, L. (2005). The nonprofit sector: Approaches, management, policy. New York, NY: Routledge.

Ashley, S. R., \& Faulk, L. (2010). Nonprofit competition in the grants marketplace. Nonprofit Management and Leadership, 21(1), 43-57. http://dx.doi.org/10.1002/nml.20011

Ashley, S. R., \& Van Slyke, D. M. (2012). The influence of administrative cost ratios on state government grant allocations to nonprofits. Public Administration Review, 72(s1), 47-56. http://dx.doi.org/10.1111/j.1540-6210.2012.02666.x

Austin, J. E. (2000). Strategic collaboration between nonprofits and business. Nonprofit and Voluntary Sector Quarterly, 29, 69-97. http://dx.doi.org/10.1177/089976400773746346

Balassiano, K., \& Chandler, S. (2010). The emerging role of nonprofit associations in advocacy and public policy: Trends, issues, and prospects. Nonprofit and Voluntary Sector Quarterly, 39, 946-55. http://dx.doi.org/10.1177/0899764009338963

Besel, K., Williams, C. L., \& Klak, J. (2011). Nonprofit sustainability during times of uncertainty. Nonprofit Management and Leadership, 22(1), 53-65. http://dx.doi.org/10.1002/nml.20040

Boris, E. T., de Leon, E., Roeger, K. L., \& Nikolova, M. (2010). Human service nonprofits and government collaboration. Washington, DC: Urban Institute. Retrieved from http://www.urban.org/UploadedPDF/412228-Nonprofit-Government-Contracting.pdf

Bowman, W. (2011). Financial capacity and sustainability of ordinary nonprofits. Nonprofit Management and Leadership, 22(1), 37-51. http://dx.doi.org/10.1002/nml.20039

Brooks, A. C. (2004). Evaluating the effectiveness of nonprofit fundraising. The Policy Studies Journal, 32, 363-374. http://dx.doi.org/10.1111/j.1541-0072.2004.00070.x

Bryson, J. M., Crosby, B. C., \& Stone, M. M. (2006). The design and implementation of cross-sector collaborations: Propositions from the literature. Public Administration Review, Special Issue: Collaborative Public Management, 66, 44-55. http://dx.doi.org/10.1111/j.1540-6210.2006.00665.x

Carroll, D. A., \& Stater, K. J. (2009). Revenue Diversification in nonprofit organizations: does it lead to financial stability? Journal of Public Administration Research and Theory, 19(4), 947-966. http://dx.doi.org/10.1093/jopart/mun025

Chang, C. F., \& Tuckman, H. P. (1994). Revenue diversification among non-profits. Voluntas: International Journal of Voluntary and Nonprofit Organization, 5, 273-290. http://dx.doi.org/10.1007/BF02354036

Crittenden, W. F. (2000). Spinning straw into gold: The tenuous strategy, funding, and financial performance linkage. Nonprofit and Voluntary Sector Quarterly, 29, 164-182. http://dx.doi.org/10.1177/089976400773746382

Eisenberg, P. (1997). A crisis in the nonprofit sector. National Civic Review, 86(4), 331-341. http://dx.doi.org/10.1002/ncr.4100860409

Eschenfelder, B. (2011). Funder-initiated integration: Partnership challenges and strategies. Nonprofit Management \& Leadership. 21(3), 273-288. http://dx.doi.org/10.1002/nml.20025 
Fairfield, K. D., \& Wing, K. T. (2008). Collaboration in foundation grantor-grantee relationships. Nonprofit Management \& Leadership, 19(1), 27-44. http://dx.doi.org/10.1002/nml.203

Foundation Center. (2013a). 25 Largest Community Foundations by Asset Size. Retrieved from http://foundationcenter.org/findfunders/topfunders/top25assets.html

Foundation Center. (2013b). 25 Largest Community Foundations by Total Giving Size. Retrieved from http://foundationcenter.org/findfunders/topfunders/top25giving.html

Froelich, K. A. (1999). Diversification of revenue strategies: evolving resource dependence in nonprofit organizations. Nonprofit and Voluntary Sector Quarterly, 28(3), 246-268. http://dx.doi.org/10.1177/0899764099283002

Gazley, B. (2008). Why not partner with local government? Nonprofit managerial perceptions of collaborative disadvantage. Nonprofit and Volunteer Sector Quarterly, 39(1), 51-76. http://dx.doi.org/10.1177/0899764008327196

Gazley, B. (2010). Linking collaborative capacity to performance measurement in government-nonprofit partnerships. Nonprofit and Voluntary Sector Quarterly, 39(4), 653-673. http://dx.doi.org/10.1177/0899764009360823

Goldman, S., \& Kahnweiler, W. M. (2000). A collaborator profile for executives of nonprofit organizations. Nonprofit Management and Leadership, 10(4), 435-450. http://dx.doi.org/10.1002/nml.10406

Greenlee, J., \& Trussel, J. (2000). Predicting the financial vulnerability of charitable organizations. Nonprofit Management and Leadership, 11, 199-210. http://dx.doi.org/10.1002/nml.11205

Gregory, A. G., \& Howard, D. (2009). The nonprofit starvation cycle. Stanford Social Innovation Review, Fall, 49-53. Retrieved from http://www.ssireview.org/articles/entry/the_nonprofit_starvation_cycle/

Guo, C., \& Acar, M. (2005). Understanding collaboration among NPOs: Combining resource dependency, institutional, and network perspectives. Nonprofit and Volunteer Sector Quarterly, 34, 340-361. http://dx.doi.org/10.1177/0899764005275411

Hager, M. (2001). Financial vulnerability among arts organizations: A test of the Tuckman-Chang measures. Nonprofit and Voluntary Sector Quarterly, 30(2), 376-92. http://dx.doi.org/10.1177/0899764001302010

Hodge, M. M., \& Piccolo, R. F. (2005). Funding source, board involvement techniques, and financial vulnerability in nonprofit organizations: A Test of Resource Dependence. Nonprofit Management and Leadership, 16(2), 171-190. http://dx.doi.org/10.1002/nml.99

Hoefer, R. (2005). Altering state policy: Interest group effectiveness among state-level advocacy groups. Social Work, 50(3), 219-27. http://dx.doi.org/10.1093/sw/50.3.219

Huxham, C., \& Vangen, S. (2000). Leadership in the shaping and implementation of collaboration agendas: How things happen in a (not quite) joined-up world. Academy of Management Journal, 43(6), 1159-1175. http://dx.doi.org/10.2307/1556343

Jackson, D. K., \& Holland, T. P. (1998). Measuring the effectiveness of nonprofit boards. Nonprofit and Voluntary Sector Quarterly, 27(2), 159-182. http://dx.doi.org/10.1177/0899764098272004

Johansen, M., \& LeRoux, K. (2013). Managerial networking in nonprofit organizations: The impact of networking on organizational and advocacy effectiveness. Public Administration Review, 73(2), 355-363. http://dx.doi.org/10.1111/puar.12017

Johnson, J. L., Daily, C. M., \& Ellstrand, A. E. (1996). Board of directors: A review and research agenda. Journal of Management, 22, 409-438. http://dx.doi.org/10.1177/014920639602200303

Jung, K., \& Moon, M. J. (2007). The double-edged sword of public-resource dependence: The impact of public resources on autonomy and legitimacy in Korean cultural nonprofit organizations. Policy Studies Journal, 35(2), 205-226. http://dx.doi.org/10.1111/j.1541-0072.2007.00216.x

Keating, E., Fischer, M., Gordon, T.P. \& Greenlee, J. (2005). Assessing financial vulnerability in the nonprofit sector. Faculty Research Working Papers Series. RWP05-002. Cambridge, MA: Harvard University.

Keating, E., Pradhan, G., Wasall, G. H., \& DeNatale, D. (2008). Passion and purpose: Raising the fiscal fitness bar for Massachusetts nonprofits. Boston, MA: The Boston Foundation. Retrieved from www.tbf.org/.../PassionPurpose\%20Raising\%20the\%20Fiscal\%20Fitness.pdf 
Kettl, D. F. (2006). Managing boundaries in American administration: The collaboration imperative. Public Administration Review 66, 10-19. http://dx.doi.org/10.1111/j.1540-6210.2006.00662.x

La Piana, D. (2010). Merging wisely. Stanford Innovation Review. Spring. Retrieved from http://www.ssireview.org/images/articles/2010SP_Feature_Merging_Wisely.pdf

Macguire, K. A. (2013). South Carolina nonprofit policies and procedures: Achieving best practices for NPOs of different sizes. Journal of Management and Sustainability, 3(3), 1-24. Retrieved from www.ccsenet.org/journal/index.php/jms/article/download/28720/17149

MacIndoe, H., \& Barman, E. (2013). How Organizational Stakeholders Shape Performance Measurement in Nonprofits: Exploring a Multidimensional Measure. Nonprofit and Voluntary Sector Quarterly, 42(4), 716-738. http://dx.doi.org/10.1177/0899764012444351

MacIndoe, H., \& Whalen, R. (2013). Specialists, Generalists, and Policy Advocacy by Charitable Nonprofit Organizations. Journal of Sociology and Social Welfare, 40(2), 119-149. Retrieved from http://www.wmich.edu/hhs/newsletters_journals/jssw_institutional/institutional_subscribers/40.2.MacIndoe .pdf

Mayer, W. J., Wang, H., Egginton, J. F., \& Flint, H. S. (2014). The impact of revenue diversification on expected revenue and volatility for non profit organizations. Nonprofit and Voluntary Sector Quarterly, 43, 374-392. http://dx.doi.org/10.1177/0899764012464696

McNutt, J. G., \& Borland, K. (1999). Electronic advocacy by nonprofit organizations in social welfare policy. Nonprofit and Voluntary Sector Quarterly, 28(4), 432-451. http://dx.doi.org/10.1177/0899764099284004

Mehta, N., \& Mehta, A. (2010). It takes two to tango: How relational investments improve IT outsourcing partnerships. Communications of the ACM, 53(2), 164. http://dx.doi.org/10.1145/1646353.1646393

Menard, S. (2002.) Applied logistic regression analysis, 106. Thousand Oaks, CA: Sage Publications.

Miller, C. (2010). The four horsemen of the nonprofit financial apocalypse. The Nonprofit Quarterly, Spring.

Mizruchi, M. S. (1996). What do interlocks do? An analysis, critique, and assessment of research on interlocking directorates. Annual Review of Sociology, 22, 271-298. http://dx.doi.org/10.1146/annurev.soc.22.1.271

Moore, M. (2012). Boston Foundation report pegs nonprofit sector at \$234B. Boston Business Journal. June 18. Retrieved

from http://www.bizjournals.com/boston/news/2012/06/07/boston-foundation-report-nonprofit.html

National Center for Charitable Statistics. (2013). Guide to Using NCCS Data. Washington D.C.: The Urban Institute. Retrieved from http://nccsdataweb.urban.org/NCCS/extracts/NCCSDataGuide2013

Nikolic, S., \& Koontz, T. (2008). Nonprofit organizations in environmental management: A comparative analysis of government impacts. Journal of Public Administration Research and Theory, 18(3), 441-463. http://dx.doi.org/10.1093/jopart/mum022

Nobbie, P. D., \& Brudney, J. L. (2003). Testing the implementation, board performance, and organizational effectiveness of the policy governance model in nonprofit boards of directors. Nonprofit and Voluntary Sector Quarterly, 32, 571 595. http://dx.doi.org/10.1177/0899764003257460

Ohlson, J. (1980). Financial ratios and the probabilistic prediction of bankruptcy. Journal of Accounting Research, 18(1), 109-31. http://dx.doi.org/10.2307/2490395

Ostrander, S. A. (2007). The growth of donor control: Revisiting the social relations of philanthropy. Nonprofit and Voluntary Sector Quarterly, 36(2), 356-372. http://dx.doi.org/10.1177/0899764007300386

Paarlberg, L. E., \& Varda, D. M. (2009). Community carrying capacity: A network perspective. Nonprofit and Voluntary Sector Quarterly, 38(4), 597-613. http://dx.doi.org/10.1177/0899764009333829

Parker, B., \& Selsky, J. W. (2004). Interface dynamics in cause-based partnerships: An exploration of emergent culture. Nonprofit and Voluntary Sector Quarterly, 33(3), 458-488. http://dx.doi.org/10.1177/0899764004266016

Pfeffer, J., \& Salancik, G. (1978/2003). The external control of organizations: A resource dependence perspective (2nd ed.). Stanford, CA: Stanford University Press.

Poole, D. L. (2008). Organizational networks of collaboration for community-based living. Nonprofit Management and Leadership, 18(3), 273-293. http://dx.doi.org/10.1002/nml.186 
Pradhan, G., \& Hindley, B. (2009). Passion and Purpose: Restructuring, Repositioning and Reinventing: Crisis in the Massachusetts Nonprofit Sector. Boston, MA: The Boston Foundation. Retrieved from http://www.tbf.org/ /media/TBFOrg/Files/Reports/PassionPurpose\%20Restructuring.pdf

Pradhan, G., \& Keating, E. (2012). Passion and Purpose Revisited: Massachusetts and the last decade's financial roller coaster. Boston, MA: The Boston Foundation. Retrieved from https://folio.iupui.edu/bitstream/handle/10244/1054/P\%26P_2012_Final.pdf

Provan, K. G., \& Milward, H. B. (1995). A preliminary theory of interorganizational network effectiveness: A comparative study of four community mental health systems. Administrative Science Quarterly, 40(1), 1-33. http://dx.doi.org/10.2307/2393698

Saxton, G. D., \& Benson, M. (2005). Social capital and the growth of the nonprofit sector. Social Science Quarterly, 86(1), 16-35. http://dx.doi.org/10.1111/j.0038-4941.2005.00288.x

Scott, J. (1990). The sociology of elites, volume 3: Interlocking directorships and corporate networks. Ann Arbor, MI: University of Michigan Press.

Selden, S. C., Sowa, J. E., \& Sandfort, J. (2006). The impact of nonprofit collaboration in early child care and education on management and program outcomes. Public Administration Review, 66(3), 412-425. http://dx.doi.org/10.1111/j.1540-6210.2006.00598.x

Shaw, M. M. (2003). The successful collaboration between nonprofit and public sectors. Nonprofit Management and Leadership, 14(1), 107-120. http://dx.doi.org/10.1002/nml.24

Silver, I. (2004). Negotiating the antipoverty agenda: Foundations, community organizations, and comprehensive community initiatives. Nonprofit and Voluntary Sector Quarterly, 33(4), 606-627. http://dx.doi.org/10.1177/0899764004269143

Sowa, J. E. (2009). The collaboration decision in nonprofit organization: Views from the front line. Nonprofit and Volunteer Sector Quarterly, 38(6), 1003-1025. http://dx.doi.org/10.1177/0899764008325247

Suárez, D. F. (2011). Collaboration and professionalization: The contours of public sector funding for nonprofit organizations. Journal of Public Administration Research and Theory, 21(2), 307-326. http://dx.doi.org/10.1093/jpart/muq049

Tinkelman, D. (1999). Factors affecting the relation between donations to not-for-profit organizations and an efficiency ratio. Research in Governmental and Nonprofit Accounting, 10, 135-161.

Trussel, J. (2002). Revisiting the prediction of financial vulnerability. Nonprofit Management and Leadership, 18, 17-31. http://dx.doi.org/10.1002/nml.13103

Tuckman, H., \& Chang, C. (1991). A methodology for measuring the financial vulnerability of charitable nonprofit organizations. Nonprofit and Voluntary Sector Quarterly, 43(2), 445-460. http://dx.doi.org/10.1177/089976409102000407

Verschuere, B., \& De Corte, J. (2014). The impact of public resource dependence on the autonomy of NPOs in their strategic decision making. Nonprofit and Voluntary Sector Quarterly, 43(2), 293-313. http://dx.doi.org/10.1177/0899764012462072

Vidovoch, L., \& Currie, J. (2012). Governance networks: Interlocking directorships of corporate and nonprofit boards. Nonprofit Management and Leadership, 22(4), 507-523. http://dx.doi.org/10.1002/nml.21042

Webb, N. J., \& Abzug, R. (2013). De-standardizing financial ratios: Again, one size does not fit all. Paper presented at the Association for Research in Nonprofit and Voluntary Action (ARNOVA), Hartford, CT.

Weerawardena, J., McDonald, R. E., \& Mort, G. S. (2010). Sustainability of nonprofit organizations: An empirical investigation. Journal of World Business, 45(4), 346-356. http://dx.doi.org/10.1016/j.jwb.2009.08.004

Werkema, R. D., Leiserson, G., \& Ansel, D. (2005). The Massachusetts nonprofit sector: An economic profile. Boston, MA: The Massachusetts Institute of a New Commonwealth. Retrieved from http://www.massinc.org/ /media/Files/Mass\%20Inc/Research/Full\%20Report\%20PDF\%20files/mass_nonp rofit.ashx

Winkler, I. (2006). Network governance between individual and collective goals: Qualitative evidence from six networks. Journal of Leadership and Organizational Studies, 12(3), 119-134. http://dx.doi.org/10.1177/107179190601200308 
Young, D. R. (ed.). (2004). Effective decision-making by nonprofit organizations. New York: The Foundation Center.

Young, D. R. (ed.). (2007). Financing nonprofits: Putting theory into practice. Walnut Creek, CA: Rowman Altamira.

\section{Notes}

Note 1. Among U.S. community foundations, The Boston Foundation ranked eighth in total giving and fifteenth in total assets in 2013 (Foundation Center, 2013a, 2013b).

Note 2. The literature suggests a two-tailed hypothesis.

Note 3. Low correlation among our selected financial ratios assessing nonprofit vulnerability concurs with previous research (Hager, 2001). Other measures that we examined but discarded for reasons of multicollinearity include surplus margin, endowment sufficiency, insolvency risk, and program disruption (Chang \& Tuckman, 1991; Greenlee \& Trussel, 2000; Keating, Fischer, Gordon, \& Greenlee, 2005; Keating, Pradhan, Wasall, \& DeNatale, 2008; Trussel, 2002).

\section{Appendix A. Description of Measures of Nonprofit Financial Vulnerability}

\begin{tabular}{|c|c|c|c|}
\hline $\begin{array}{l}\text { Measure of } \\
\text { Financial Vulnerability }{ }^{1}\end{array}$ & Description & Formula & Source \\
\hline Funding Disruption & $\begin{array}{l}\text { As percentage increases, organization } \\
\text { becomes increasingly unstable as a result of } \\
\text { decreasing revenue. A percentage of } .25 \text { or } \\
\text { more is considered "at-risk." }\end{array}$ & $-1 * \frac{\left(\text { Total Revenue }^{\mathrm{T} 2}-\text { Total Revenue }^{\mathrm{T} 1}\right)}{\text { Total Revenue }^{\mathrm{T} 1}}$ & Keating et al. (2005) \\
\hline Debt Ratio & $\begin{array}{l}\text { As the percentage increases, organizations } \\
\text { become increasingly more encumbered with } \\
\text { debt and potentially less stable. }\end{array}$ & $\frac{\text { Total Liabilities }}{\text { Total Assets }}$ & $\begin{array}{l}\text { Ohlson (1980) } \\
\text { Tuckman \& Chang (1991) } \\
\text { Trussel (2002) }\end{array}$ \\
\hline $\begin{array}{l}\text { Administrative Expense } \\
\text { Ratio }\end{array}$ & $\begin{array}{l}\text { As percentage increases, organizations } \\
\text { become increasingly more encumbered with } \\
\text { overhead costs and potentially less flexible in } \\
\text { meeting program needs. }\end{array}$ & $\frac{\text { Administrative Expenses }}{\text { Total Revenue }}$ & Tuckman \& Chang (1991) \\
\hline $\begin{array}{l}\text { Herfindahl Index } \\
\text { (normalized) }\end{array}$ & $\begin{array}{l}\text { A percentage moves towards upper end of the } \\
\text { scale, organization's revenue becomes more } \\
\text { concentrated and potentially more vulnerable } \\
\text { to revenue shocks. }\end{array}$ & $\begin{array}{l}\mathrm{N} \\
\mathrm{H}=\Sigma \mathrm{s}_{\mathrm{i}} 2 \\
\mathrm{i}=1\end{array}$ & $\begin{array}{l}\text { Tuckman \& Chang (1991) } \\
\text { Trussel (2002) }\end{array}$ \\
\hline $\begin{array}{l}\text { Reliance on Commercial } \\
\text { Revenue }^{2}\end{array}$ & $\begin{array}{l}\text { As percentage increases, organization } \\
\text { becomes increasingly more reliant on } \\
\text { commercial revenue. }\end{array}$ & $\frac{\text { Commercial Revenue }}{\text { Total Revenue }}$ & Keating et al. (2005) \\
\hline
\end{tabular}

Notes. ${ }^{1}$ As the value of each measure increases, the financial vulnerability of the nonprofit increases. ${ }^{2}$ Includes program service fees, dues, profit from sale of inventory, and other revenues. 


\section{Appendix B. Correlations}

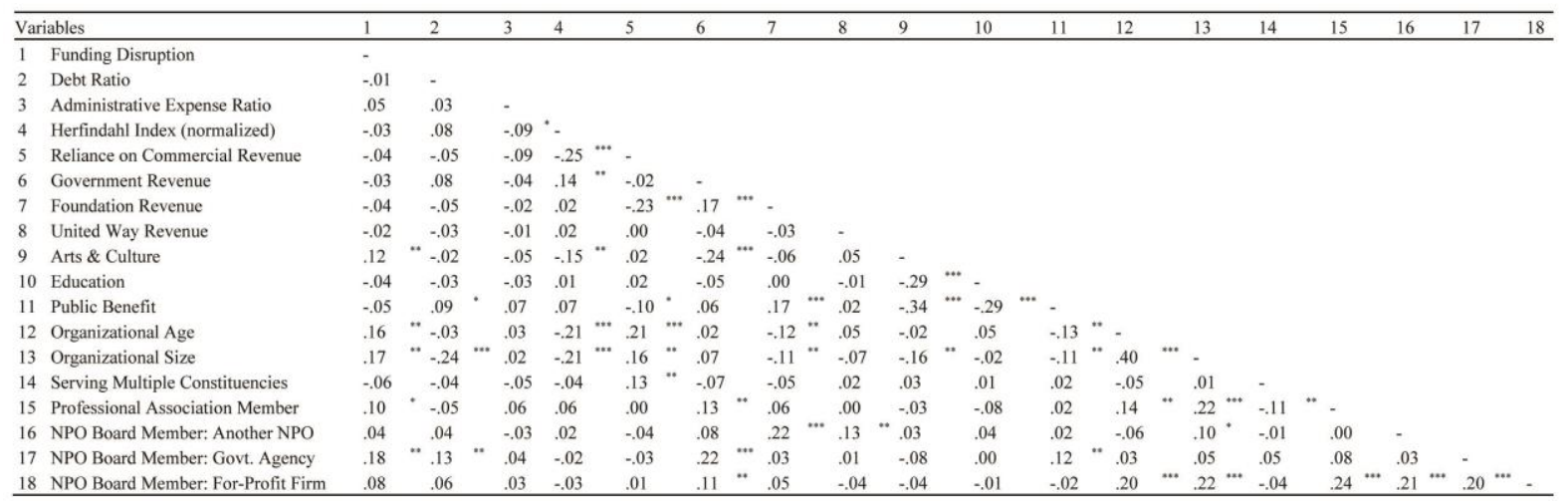

$* * * \mathrm{p}<.001, * * \mathrm{p}<.05, * \mathrm{p}<.10$ (two-tailed tests).

\section{Copyrights}

Copyright for this article is retained by the author(s), with first publication rights granted to the journal.

This is an open-access article distributed under the terms and conditions of the Creative Commons Attribution license (http://creativecommons.org/licenses/by/3.0/). 